Українські залізниці. - 2014. - Вип.9. - С. 22-29.

7. Крикавський Є.В. Логістика. Львів: Вид-во держ. ун-ту "Львівська політехніка", 2004. - 447 с.

8. Крикавський $€$. Україна у глобальних ланцюгах поставок

Є. Крикавський, Н. Чорнописька // Логістика: теорія та практика. - 2012. - № . 1. - C. $92-100$.

9. Сумец А.М. Логистика: Теория, ситуации, практические задания: учебное пособие. - К.: Хай-Тех Пресс, 2008. — 320 c.

10. Алькема В.Г., Сумець О.М. Логістика: Теорія та практика: навчальний посібник. - Київ: Вид. дім "Професіонал", 2008. -270 c.

11. Джонсон Джеймс Вуд, Дональд Ф., Вордлоу Деніел Л., Мерфи-мл., Поль Р. Современная логистика. - 7-е издание: пер. с анл. - М.: издательский дом "Вильямс", 2002. — 624 с.

12. Кальченко А.Г., Кривещенко В.В. Логістика: навч. Посіб. - Вид. 2-ге, без змін. - К.: КНЕУ, 2008. - 472 с.

13. Модели и методы теории логистики: учебное пособие. - 2-е изд./Под ред. В.С. Лукинского. - СПб.: Питер, 2007. - 448 с.

\title{
ВДОСКОНАЛЕННЯ СИСТЕМИ МАТЕРІАЛЬНОГО-ТЕХНІЧНОГО ЗАБЕЗПЕЧЕННЯ НАЦІОНАЛЬНОЇ ГВАРДІЇ УКРАЇНИ 3 УРАХУВАННЯМ КОРУПЦІЙНИХ РИЗИКІВ
}

\author{
Гафуров О.В., к.т.н., ст. викладач (НА НГУ)
}

В статті запропоновано вдосконалення системи матеріального-технічного забезпечення Начіональної гвардії Украӥни з урахуванням корупційних ризиків. Проведено аналіз проблеми корупиії у сфері військових закупівель. Досліджені основні ризики під час військових закупівель для Національної гвардії Украӥни. У дослідженні запропоновані напрями подолання корупиійних ризиків в рамках вдосконалення системи матеріальноготехнічного забезпечення Начіональної гвардії Украӥни в сучасних умовах.

Ключові слова: матеріальне забезпечення, військовий підрозділ, бюджсетні кошти, корупційні ризики, логістична система.

\section{СОВЕРШЕНСТВОВАНИЯ СИСТЕМЫ МАТЕРИАЛЬНО- ТЕХНИЧЕСКОГО ОБЕСПЕЧЕНИЯ НАЦИОНАЛЬНОЙ ГВАРДИИ УКРАИНЫ С УЧЕТОМ КОРРУПЦИОННЫХ РИСКОВ}

\author{
Гафуров А.В., к.т.н., ст. преподаватель (НА НГУ)
}

В статье предложено исследование совершенствования системы материального-технического обеспечения Национальной гвардии Украины с учетом коррупционных рисков. Проведен анализ проблемы коррупщии в сфере военных закупок. Исследовань основные риски во время военных закупок для Наџиональной гвардии 
Украины. В исследовании предложены направления преодоления коррупционных рисков в рамках совершенствования системь материального-технического обеспечения Национальной гвардии Украины в современных условиях..

Ключевые слова: материальное обеспечение, военное подразделение, бюджетные средства, коррупционые риски, логистическая система.

\title{
IMPROVEMENT OF THE MATERIAL AND TECHNICAL SUPPORT SYSTEM OF THE NATIONAL GUARD OF UKRAINE TAKING INTO ACCOUNT CORRUPTION RISKS
}

\author{
Gafurov O.V., candidate of technical sciences, Senior Lecturer \\ ( National Academy of the National Guard of Ukraine)
}

At the present stage, effective material and technical support of the military units of the National Guard of Ukraine seems possible only if the corruption that may take place in the process of military procurement is overcome. The transparent scheme of procurement organization will create opportunities for improvement of the entire system of material and technical support of the units of the National Guard of Ukraine and bring it closer to international standards. Products, works and services that constitute state secrets are procured without the use of competitive procedures.

According to the requirements of the Law of Ukraine "On State Defense Order", state purchases are made only by economic entities that are registered as producers of products, works and services of defense purposes.

The procedure for the formation and maintenance of the Register of producers of products, works and services for defense purposes, the procurements of which constitute state secrets, is determined by the Cabinet of Ministers of Ukraine. Responsibility for the selection and application of procurement procedures is solely for the official (official) of the customer - members of the competition committee personally.

One of the difficult issues that the Ministry of Defense of any country in the world must solve on a regular basis is in the plane of choice between independent production or the creation of the necessary military equipment, infrastructure, material and technical facilities and services, on the one hand, and their procurement, on the other side This choice will ultimately depend on two key factors. The first is an analysis of the possible choice in terms of effectiveness, and the second is an analysis in terms of effectiveness.

An efficiency analysis justifies the need to change the size and composition of defense infrastructure, as well as logistical support for this infrastructure in accordance with existing and future threats, and is carried out jointly with other members and alliance partners. The performance analysis determines the optimal structure of forces and resources and explores opportunities for reducing the cost of defense activities and / or improving its effectiveness.

Key words: material support, military unit, budget funds, corruption risks, logistics system.

Постановка проблеми та їі зв'язки з науковими чи практичними завданнями. На сучасному етапі ефективне забезпечення матеріально-технічне Національної гвардії України уявляється можливим лише за умови подолання корупції, яка може мати місце в процесі здійснення військових закупівель. Прозора схема організації закупівель створить можливості вдосконалення всієї системи матеріально-технічного забезпечення 
підрозділів Національної гвардії України та приблизить іiі до міжнародних стандартів.

Аналіз останніх досліджснь $i$ публікацій та виділення невирішених частин загальної проблеми. В роботах [13] подані нормативні документи та стандарти, які регламентують матеріальне забезпечення військових підрозділів. В дослідженнях Е. Волкова, О. Голоти та ін. $[4,5]$ виділяються економічні чинники воєнної безпеки. Роботи Є. Гороховського та О. Іщенка $[6,7]$ присвячені проблемам управління системою матеріальнотехнічного забезпечення військових підрозділів. В дослідженнях В. Кивлюка, І. Романенка, Т. Савенкової та ін. [8-10] розглядаються погляди на розвиток системи

В результаті аналізу спеціалізованої літератури виявлено вельми актуальне значення проблематики вдосконалення системи матеріального-технічного забезпечення Національної гвардії України 3 урахуванням корупційних ризиків. Але літературні джерела не містять системного аналізу управління матеріальним забезпеченням Національної гвардії України 3 урахуванням корупційних ризиків.

Отже, метою статті є дослідження вдосконалення системи матеріальноготехнічного забезпечення Національної гвардії України 3 урахуванням корупційних ризиків.

Для досягнення поставленої мети вирішувалися наступні задачі:

- аналіз проблеми корупції у сфері військових закупівель;

- дослідження основних ризиків під час військових закупівель;

- формування напрямів подолання

корупційних ризиків в рамках вдосконалення системи матеріальноготехнічного забезпечення Національної гвардії України.

Виклад основного матеріалу дослідження. Вагомою проблемою українського суспільства $\epsilon$ наявність корупції, зокрема в бюджетній сфері.

Збиток держави в результаті

державних закупівель включає до себе:

- фінансові втрати - укладання

угод на невигідних для держави i

суспільства фінансових умовах;

- кількісні втрати - завищення

або заниження обсягу матеріалів, що

постачаються, і наданих послуг, порівняно

3 необхідною кількістю і т.п.;

- якісні втрати - укладення угод 3

порушенням необхідних технічних умов,

таких як постачання товарів, виконання

робіт або надання послуг неналежної

якості і т.п;

- політичні втрати - погіршення

інвестиційного клімату в країні, втрата довіри 3 боку громадян до державних структур і держави в цілому і т.п.

Вирішення проблеми корупції у сфері військових закупівель має передбачати:

- розуміння проблеми (складання схеми корупційного ризику;

- забезпечення доброчесності під час процесу;

- прийняття рішень на основі об'єктивних факторів;

суб'єктів; залучення усіх ключових

- делегування повноважень;

- звітність за результати та

ефективність;

- збереження прозорості в

нестійкому середовищі.

Основні ризики під час військових закупівель наступні.

На етапі визначення потреби в закупівлі:

- уникнення

процедури

відкритих торгів;

- завищення потреби в обсягах та планування закупівлі військового майна, у якому не було потреби взагалі чи яке не прийняте на озброєння (постачання);

- застаріли стандарти військової форми щодо розмірів, ростовки та якості 
(як наслідок закупівля товару не належної якості).

На етапі визначення очікуваної вартості предмету закупівлі:

- відсутність затверджених

методик визначення очікуваної вартості предмету закупівлі;

- відсутність порядку здійснення контролю за процедурою визначення очікуваної вартості предмету закупівлі;

- наявність прямої можливості визначення та отримання посадовими особами “подяки” від виконавців.

На етапі розробки проекту документації конкурсних торгів:

- формування умов проекту документації конкурсних торгів під “свого” учасника торгів;

- залучення до участі в торгах технічних учасників;

- застарілі технічні норми та вимоги до предмету закупівель.

На етапі організації роботи комітету 3 конкурсних торгів:

- не своєчасне ознайомлення зі зразками предмету закупівель для визначення відповідності зразкаметалонам.;

- змова членів комітету торгів 3 учасниками тендерних закупівель;

- проведення переговорної процедури не забезпечує виявлення найкращого учасника;

\section{- $\quad$ не}

законодавством порядок проведення переговорів, вибору учасників, вимоги до документації, етапи проведення переговорів.

Продукція, роботи і послуги, які становлять державну закуповуються без конкурентних процедур.

Згідно вимог Закону України "Про державне оборонне замовлення" державні закупівлі здійснюються лише у суб'єктів господарювання, що зареєстровані як виробники продукції, робіт і послуг оборонного призначення.
Порядок формування та ведення Реєстру виробників продукції, робіт i послуг оборонного призначення, закупівлі яких становлять державну таємницю (Реєстр), визначається Кабінетом Міністрів України (Постанова КМУ «Про затвердження Порядку формування та ведення реєстру виробників продукції, робіт і послуг оборонного призначення, закупівлі, яких становлять державну таємницю» [11]).

Органами контролю та регулювання державних закупівель являються наступні: - уповноважений орган Міністерство економічного розвитку та торгівлі - регулює сферу державних закупівель, а у разі виявлення порушень законодавства має право надавати рекомендації щодо їх усунення;

- контролюючі органи:

- Державна казначейська служба - перевіряє наявність та відповідність документів замовника i не проводить платежі при виявленні порушень;

- Антимонопольний комітет України - контролює дотримання конкуренції під час державних закупівель, розглядає скарги учасників;

- Держфінінспекція - контролює законне та ефективне витрачання державних коштів;

- Рахункова палата України уповноважена парламентом на здійснення контролю за законним, ефективним витрачанням державних коштів.

Також, органом контролю та регулювання державних закупівель $\epsilon$ Державна служба статистики України i правоохоронні органи в межах компетенції, визначеної Конституцією й законами України.

Відповідальність за вибір та застосування процедур закупівлі несуть виключно службові (посадові) особи замовника - члени комітету 3 конкурсних торгів персонально.

Склад комітету з конкурсних торгів та положення про комітет 3 конкурсних торгів затверджуються рішенням 
замовника (генерального замовника). До складу комітету входить не менше п’яти осіб, які не можуть бути посадовими особами та представниками учасників, членами їх сімей, народними депутатами України та депутатами місцевих рад.

Одне з важких питань, які постійно мають вирішувати міністерства оборони будь-якої з країн світу, лежить у площині вибору між самостійним виробництвом чи створенням необхідного військового обладнання, інфраструктури, матеріальнотехнічних засобів і послуг, з одного боку, та їх закупівлею, з другого боку. Цей вибір у кінцевому рахунку залежатиме від двох ключових чинників. Перший - це аналіз можливого вибору 3 точки зору ефективності, а другий - аналіз 3 точки зору результативності. Прикладами аналізу з точки зору ефективності можуть слугувати аналіз оборонної стратегії США «Quadrennial Defense Review», що здійснюється один раз на чотири роки, а також аналіз «Base Realignment and Closure», де розглядається й обгрунтовується доцільність перепрофілювання чи закриття військових баз. Аналіз з точки зору ефективності обгрунтовує необхідність зміни розміру та складу оборонної інфраструктури, а також діяльності 3 матеріально-технічної підтримки цієї інфраструктури у відповідності з існуючими та майбутніми загрозами, та здійснюється спільно 3 іншими членами й партнерами альянсу. Аналіз 3 точки зору результативності визначає оптимальну структуру сил i засобів та досліджує можливості для зниження вартості оборонної діяльності та/чи підвищення її результативності.

У якості напрямів подолання корупційних ризиків в рамках вдосконалення системи матеріальноготехнічного забезпечення Національної гвардії України можна запропонувати наступні:

формування нової свідомості та побудова доброчесності [12];
- сильна політична воля i підтримка на рівні вищого керівництва, єдність і стабільність політики;

- інституційна спроможність структур i персоналу, який здійснює реформи, безперервний професійний розвиток;

- спільні зусилля керівництва i персоналу як цивільного, так і військового; - правильні стратегія i фокус, баланс між важкими і легкими завданнями, делегування повноважень;

- утримання сподівань у визначених рамках;

- прозорість i чесний діалог із засобами масової інформації;

- моніторинг та оцінювання результатів через певні проміжки часу;

- залучення зовнішніх сторін 3МI, громадських організацій, волонтерів, науковців;

- $\quad$ міжнародна підтримка;

- зовнішня незалежна оцінка.

Висновки: Таким чином, в даному дослідженні були вирішені наступні наукові та практичні завдання:

були проаналізовані шляхи вирішення проблеми корупції у сфері військових закупівель та визначено збиток держави в результаті корупційних схем державних закупівель для потреб Національної гвардії України;

- виконано дослідження основних ризиків під час військових закупівель i проаналізовано державні нормативні документи, які регламентують матеріальне забезпечення військових підрозділів;

- виділено напрями подолання корупційних ризиків в рамках вдосконалення системи матеріальноготехнічного забезпечення Національної гвардії України;

\section{ПЕРЕЛІК ВИКОРИСТАНИХ ДЖЕРЕЛ}

1. Про затвердження Положення

про продовольче забезпечення
Національної гвардії України в мирний час [Електронний ресурс]: наказ МВС України. 
2015. - № 1118. - Режим доступу: http://zakon2.rada.gov.ua/laws/show/z1169-

15 ?test $=$ XX7MfyrCSgkyot 7

IZiOtR2A7HI4kos80msh8Ie6

2. Біла книга 2007. Оборонна політика України. - К.: МОУ, 2008. - 120 с.

3. Біла книга - 2010. Збройні Сили України. - К.: МОУ, 2011. - 79 с.

4. Волкова, Е. Основные проблемы управления материальными запасами / Е.Волкова, Г.А.Портнова // Актуальні питання менеджменту в сучасних умовах / Донец. нац. техн. ун-т. - Донецьк, 2007. c. $288-290$.

5. Голота, О. П. Економічні чинники воєнної безпеки / О.П. Голота // Стратегічні пріоритети, 2015. - 312 с.

6. Гороховський, Є. Тил Збройних Сил України: надійність в ім'я боєздатності / Є. Гороховський // Військо України. - 2011.- №1. - С. 26 - 29.

7. Іщенко, О. В. Орган управління системою матеріально-технічного забезпечення Збройних Сил України, яким йому бути? - Електронний ресурс - Режим доступу:

http://defpol.org.ua/site/index.php/uk/arhiv/k olonkaavtora/3109-2015-09-27-09-18-56 (11.01.2013). - Загол. з екрану.
8. Кивлюк, В. С. Погляди на формування та функціонування системи матеріально-технічного забезпечення Збройних Сил України / В.С. Кивлюк // Наука і оборона. - 2006.- №2.- С. 22-27.

9. Романченко, I.C. Погляди на розвиток системи матеріально-технічного, забезпечення Збройних Сил України / I.C Романченко., В.О. Шуєнкін // Наука i оборона. - 2007.- №4.- С. 22-27.

10. Савенкова, Т. И. Логистика: уч. пособие для вузов / Т. И. Савенкова - 3-е изд., стер. - М.: Омега-Л, 2008. - 255 с.

11. Про затвердження Порядку формування та ведення реєстру виробників продукції, робіт і послуг оборонного призначення, закупівлі, яких становлять державну таємницю [Електронний ресурс]: Постанова КМУ 17 березня 2011 р. № 262 зі змінами - Режим доступу: http://zakon.rada.gov.ua/laws/show/262-

2011-\%D0\%BF

12. Каличева Н.Є. Вплив соціальної відповідальності на розвиток бізнесу в Україні/ Н.Є. Каличева, К.В. Діденко, В.В. Ільєнков// Причорноморські економічні студії: науковий журнал. - Одеса, Причорноморський науково-дослідний інститут економіки та інновацій,2018. Вип. 28. - Ч. 1.- С. 79-81

DOI 10.18664/338.47:338.45.v0i64.149914

\title{
УДК 658.7
}

\section{БАР'СРИ РОБОТИ МІЖНАРОДНИХ ЛОГІСТИЧНИХ СИСТЕМ}

\author{
Дикань О.В., д.е.н, професор, \\ Білецька Д.О., аспірант, \\ Смоляр С.В., магістрант (УкрДУЗТ)
}

Стаття присвячена аналізу проблем міжнародної логістики. Особливість міжнародної логістики полягає в тому, щуо виробник і споживач продукиї знаходяться в різних державах і тому логістичний ланцюг поставок формується з урахуванням проходження державних кордонів і митниць. Одна з характерних складнощів, в зв'язку

(C) Дикань О.В.,

Білецька Д.О.,

Смоляр С.В.

Вісник економіки транспорту і промисловості № 64, 2018 